\title{
Development of cereal bars with adequate nutritional profile for each trimester of pregnancy-An exploratory study
}

\author{
Desenvolvimento de barritas de cereais com perfil nutricional adequado a cada trimestre da \\ gravidez - Um estudo exploratório
}

\author{
Sara Sofia Montenegro ${ }^{1}$, António Raposo ${ }^{1}$, Bruno de Sousa ${ }^{1}$, Nelson Tavares ${ }^{1}$ \\ ${ }^{1} \mathrm{CBIOS}$ (Research Center for Biosciences and Health Technologies), Universidade Lusófona de Humanidades e \\ Tecnologias, Campo Grande 376, 1749-024 Lisboa, Portugal \\ Email: sarasmontenegro@gmail.com
}

\begin{abstract}
Nutrition plays a crucial role in pregnancy as it may help to prevent pregnancy complications and fetal pathologies. It is beneficial for pregnant women to have a fractionated alimentation, as it minimizes symptoms of hyperemesis gravidarum and reduces the increased risk of hypoglycemia.

The objective of this study was the preparation of three cereal bars, each one suitable for a trimester of pregnancy for pregnant women without known nutritional deficiency or pathology.

Three cereal bars with a common base were obtained, to which were added nutritionally adequate ingredients for the nutritional needs of each respective trimester.

The bars respected the increase of the caloric intake during the pregnancy, but, in terms of micronutrients, it was verified that no micronutrient has reached the total Dietary Reference Intake (DRI) through the consumption of two cereal bars. Still, these bars may become important tools for adherence and maintenance of healthy alimentation by the pregnant woman.
\end{abstract}

Keywords: Cereal bars; nutrients; pregnancy.

\section{Resumo}

A nutrição desempenha um papel vital na gravidez porque ajuda a prevenir complicações da mesma e patologias no feto. É benéfico para as grávidas terem uma alimentação polifraccionada, pois minimiza sintomas de hiperémese gravídica e diminui o risco acrescido de hipoglicemia. O objetivo deste estudo era a elaboração de três barritas de cereais, cada uma adequada a um trimestre da gravidez, para grávidas que não tenham patologia ou carência nutricional.

Obtiveram-se três barritas de cereais, com uma base comum, à qual foram acrescentados ingredientes nutricionalmente adequados às necessidades de cada trimestre. As barritas respeitaram o aumento da ingestão calórica ao longo da gravidez, porém, verificou-se que nenhum dos micronutrientes atingia a totalidade da Dose Diária Recomendada (DDR) através do consumo de duas barritas. Ainda assim, estas barritas de cereais poderão constituir-se como ferramentas importantes na adesão e manutenção de uma alimentação saudável por parte da grávida.

Palavras - Chave: Barritas de cereais, nutrientes, gravidez 


\section{Introduction}

Nutrition plays a vital role in pregnancy ${ }^{1}$ because it may help to prevent complications $\mathrm{s}^{2,3}$ such as gestational diabetes or hypertension (pre-eclampsia) ${ }^{4}$. Hypertension during pregnancy can have negative consequences for both mother and fetus, increasing the likelihood of these women developing pre-eclampsia ${ }^{5}$. Another pathology that pregnant woman may develop, especially if overweight or obese, is gestational diabetes, which can lead into type 2 diabetes mellitus in $5-10 \%$ of the cases $^{6}$. Alimentation during pregnancy may contribute to the development of fetal pathologies, influence fetal development and may contribute to an easier delivery ${ }^{2,3,7}$. The nutritional intake of the pregnant woman may also have some influence on the phenotype of the fetus through epigenetic programation ${ }^{8}$. In this way, nutritional counseling assumes that it is a cornerstone of prenatal care for all pregnant women, in which an individualized approach should be considered on several aspects: access to food, socioeconomic status, race, ethnicity, culture, Body Mass Index (BMI) and the existence of any pathology ${ }^{3,4}$.

During pregnancy, nutritional requirements are modified both in terms of macro and micronutrients ${ }^{2}$. There should be a consumption of $1.1 \mathrm{~g}$ of protein $/ \mathrm{kg}$ of body weight, and carbohydrates should provide $45-64 \%$ of the total calories consumed daily. Lipid requirements do not change in pregnancy, and should supply $20-35 \%$ of the total calories consumed ${ }^{2}$.

During pregnancy there is an increased need for some micronutrients, such as folic acid, iron and iodine, which perform very important organic and/or metabolic functions both for fetus and for the mother ${ }^{9}$ (Table 1).

These are some of the most important nutrients for pregnant women: Folate / Folic acid: In Portugal, pregnant women are advised supplement with folic acid ${ }^{10}$, since it besides the aforementioned benefits it has also been shown to be efficient in reducing the risk of preeclampsia ${ }^{11}$ and spina bifida $^{12}$. Examples of foods rich in folates are nuts, citrus fruits, vegetables, and wheat flakes ${ }^{3}$.

Iron: The ingestion of this nutrient has been shown to be effective in the prevention of anemia ${ }^{13}$, a relevant fact because the children of anemic pregnant women have lower birth length ${ }^{14,15}$ and weight and lower Apgar score $^{15}$. Additionally, anemia may cause cardiac and respiratory pathologies ${ }^{16,17}$. The recommended doses of this nutrient during pregnancy is $27 \mathrm{mg} / \mathrm{day}^{3}$ (Table1). Zinc: Zinc plays crucial roles in multiple biological processes in the body, and maternal serum levels may influence the baby's birth

\section{Introdução}

A nutrição desempenha um papel vital na gravidez ${ }^{1}$, pois pode ajudar a prevenir complicações da mesma ${ }^{2,3}$ tais como: diabetes gestacional ou hipertensão (pré-eclâmpsia $)^{4}$. A hipertensão durante a gravidez pode ter consequências negativas, quer para a mãe quer para o feto, aumentando a probabilidade do desenvolvimento de pré-eclâmpsia 5 . Outra patologia que a grávida pode vir a desenvolver, sobretudo se tiver excesso de peso ou obesidade é a diabetes gestacional, que pode levar à diabetes mellitus tipo 2 em 5 a $10 \%$ dos $\operatorname{casos}^{6}$. A alimentação durante a gravidez pode contribuir para o surgimento de patologias do feto, influencia o desenvolvimento fetal e pode contribuir para um parto mais fácili2,3,7. $\mathrm{O}$ aporte nutricional da grávida pode também ter alguma influência no fenótipo do feto através da programação epigenética ${ }^{8}$. Desta forma, o aconselhamento nutricional assume-se como sendo uma pedra basilar dos cuidados pré-natais para todas as grávidas, no qual deverá ser feita uma abordagem individualizada que tenha em consideração vários aspetos: o acesso a alimentos, o status socio-económico, a raça, a etnia, a cultura, o Índice de Massa Corporal (IMC) e ainda a existência de alguma patologia ${ }^{3,4}$.

Ao longo da gravidez existe uma alteração nas necessidades nutricionais, quer em termos de macro quer de micronutrientes $^{2}$. Deve haver um consumo de $1,1 \mathrm{~g}$ de proteína/kg de peso e hidratos de carbono que deverão fornecer $45-64 \%$ das calorias totais ingeridas diariamente. As necessidades lipídicas não se alteram na gravidez, devendo estes serem fornecedores de $20-35 \%$ das calorias totais ingeridas ${ }^{2}$.

Durante a gravidez, verifica-se um aumento das necessidades de alguns micronutrientes, nomeadamente de ácido fólico, ferro, zinco e iodo, que desempenham funções orgânicas e/ou metabólicas muito importantes quer para o feto quer para a mãe ${ }^{9}$ (Tabela1).

Os outros micronutrientes, apesar de não sofrerem aumentos significativos, devem ser integralmente assegurados, devido às funções orgânicas e metabólicas que regem.

Folato/Ácido fólico: Em Portugal as grávidas são aconselhadas a fazer suplementação de ácido fólico ${ }^{10}$, uma vez que este demonstrou ser eficiente na redução do risco de pré-eclâmpsia ${ }^{11}$ e de espinha bífida ${ }^{12}$. O folato pode ser naturalmente encontrado em alimentos como frutos secos, citrinos, vegetais, e flocos de trigo ${ }^{3}$.

Ferro: A ingestão deste nutriente tem demonstrado ser eficaz na prevenção da anemia ${ }^{13}$, um facto relevante, pois filhos de grávidas anémicas apresentam menor comprimento $^{14,15}$, peso à nascença e valor de Apgar me- 
weight $^{18}$. The correct dose is $11 \mathrm{mg} /$ day $^{3}$ (Table1). Magnesium: Magnesium consumption during pregnancy is associated with a decreased risk of pre-eclampsia, premature births, and intrauterine growth retardation ${ }^{19}$. In Portugal, a study concluded that pregnant women had an inadequate intake of this micronutrient ${ }^{20}$. The recommended daily dose is $350 \mathrm{mg}^{3}$. Iodine: Iodine deficiency in pregnancy may be associated with deficits in fetal neurological development ${ }^{21}$. In Portugal, guidelines recommend supplementation with potassium iodide $(150-200 \mu \mathrm{g} / \text { day })^{10}$, accompanied by dietary sources of iodine for preconception, pregnant, and women who are breastfeeding exclusively ${ }^{22}$.

Vitamin D: Vitamin D supplementation is indicated for the prevention of pre-eclampsia ${ }^{23}$; however, a consensus for daily intake during pregnancy has not been met $^{24}$. The recommended daily dose is $5 \mu \mathrm{g} /$ day (Table $1)$.

Calcium: Consumption of this mineral is important in order to prevent the loss of maternal bone mass ${ }^{25}$. Cereal bars fortified with this mineral can be an effective source to promote increased consumption ${ }^{26}$.

Vitamin C: The consumption of fruit rich in vitamin C is very important because, specifically during the period of pregnancy, this type of nutrient prevents the development of complications, specially in type 1 diabetic women, such as abnormalities of fetal bone development $^{27}$. This vitamin also allows an increase the absorption of iron. Foods rich in vitamin C include: broccoli, cabbage, kiwi, orange, strawberries, lemon, clementine, and raspberries ${ }^{28}$. The recommended daily doses is $85 \mathrm{mg} /$ day (Table 1).

The risk of hypoglycemia is increased during pregnancy, which can put the life of the fetus at risk ${ }^{29}$. Thus, it is essential that pregnant women can ingest a balanced and adequate snack in order to maintain stable serum glucose levels.

The objective of this work was therefore the preparation of three cereal bars with content appropriate to each trimester of the pregnancy. These bars should be recommended to pregnant women over 18 years with no underlying nutritional pathology or deficiencies. nores ${ }^{15}$. Além de que a anemia pode ter consequências cardio-respiratórias para a mãe $\mathrm{e}^{16,17}$. O aporte aconselhado deste nutriente na gravidez é de $27 \mathrm{mg} / \mathrm{dia}^{3}$ (Tabela $1)$.

Zinco: O zinco desempenha funções cruciais em diversos processos biológicos do organismo, sendo que os níveis séricos deste nutriente podem influenciar o peso no nascimento ${ }^{18}$. A dose aconselhada é de $11 \mathrm{mg} / \mathrm{dia}^{3}$ (Tabela 1).

Magnésio: O consumo de magnésio durante a gravidez está associado à diminuição do risco de pré-eclâmpsia, de nascimentos prematuros e de atraso no crescimento intrauterino ${ }^{19}$. Em Portugal, um estudo verificou existir um aporte inadequado deste micronutriente em mulheres grávidas ${ }^{20}$. A dose diária recomendada é de $350 \mathrm{mg}^{3}$. Iodo: A deficiência de iodo na gravidez pode estar associada a défices de desenvolvimento neurológico no feto $^{21}$. Em Portugal as diretrizes recomendam uma suplementação com iodeto de potássio $(150-200 \mu \mathrm{g} / \mathrm{dia})^{10}$ acompanhada de uma alimentação que inclua fontes de iodo às mulheres em preconcepção, grávidas e mulheres que se encontrem em amamentação exclusiva ${ }^{22}$. Vitamina D: A suplementação de vitamina D está indicada na prevenção da pré-eclâmpsia ${ }^{23}$, ainda que, a sua toma diária durante a gravidez não reúna consenso ${ }^{24}$. A dose recomendada é de $5 \mu \mathrm{g} / \mathrm{dia}$ (Tabela 1 ).

Cálcio: O consumo deste mineral é importante para prevenir a perda de massa óssea materna ${ }^{25}$. As barritas de cereais fortificadas com este mineral podem constituir uma fonte eficaz para aumentar o consumo deste nutriente ${ }^{26}$

Vitamina C: A ingestão de frutas ricas em vitamina $\mathrm{C}$ é muito relevante porque, especialmente durante o período de gravidez, este tipo de nutriente previne o desenvolvimento de complicações ${ }^{27}$ especialmente em mulheres com diabetes tipo 1 , tais como desenvolvimento anormal do tecido ósseo fetal ${ }^{27}$. Esta vitamina permite igualmente um aumento da absorção do ferro. Alimentos ricos nesta vitamina incluem: brócolos, couves, kiwi, laranja, morangos, limão, clementina e framboesas ${ }^{28}$. A dose diária recomendada é $85 \mathrm{mg}$ (Tabela 1). O risco de hipoglicémia está aumentado durante a gravidez, condição que pode colocar a vida do feto em ris$\mathrm{co}^{29}$. Assim, é imperioso que as grávidas possam ingerir snacks adequados de modo a manter os níveis de glicemia estáveis.

O objetivo deste trabalho foi a elaboração de três barritas, que sejam adequadas nutricionalmente, a cada trimestre da gravidez. Estas barritas seriam aconselhadas a grávidas com idade superior a 18 anos e que não tivessem qualquer patologia ou carências nutricionais. 
Table 1 - Daily Micronutrient Recommendations for Adult Women2,3

\begin{tabular}{|c|c|c|c|}
\hline Nutrient & Non pregnant & Pregnant & Lactating \\
\hline Energy(kcal) & 2403 & $\begin{array}{l}\text { 2nd trimester-2743 } \\
\text { 3rd trimester - } 2855\end{array}$ & 2698 \\
\hline Protein $(\mathrm{g} / \mathrm{kg} / \mathrm{d})$ & 0.8 & 1.1 & 1.1 \\
\hline Carbohydrates (g/d) & 130 & 175 & 210 \\
\hline Fiber & 25 & 28 & 29 \\
\hline Linoleic acid (g/d) & 12 & 13 & 13 \\
\hline $\begin{array}{l}\text { Alfa-Linolenic Acid } \\
\text { (g/d) }\end{array}$ & 12 & 13 & 13 \\
\hline Folic Acid & 400 & 600 & 500 \\
\hline Iodine (g) & 150 & 175 & 200 \\
\hline Magnesium (mg) & 320 & 350 & 310 \\
\hline Vitamin A $(\mu \mathrm{g} / \mathrm{d})$ & 700 & 770 & 1300 \\
\hline Vitamin D $(\mu \mathrm{g} / \mathrm{d})$ & 5 & 15 & 15 \\
\hline Vitamin E (mg/d) & 15 & 15 & 19 \\
\hline Vitamin $K(\mu g / d)$ & 90 & 90 & 90 \\
\hline Folate $(\mu \mathrm{g} / \mathrm{d})$ & 400 & 600 & 500 \\
\hline Niacin $(\mathrm{mg} / \mathrm{d})$ & 14 & 18 & 17 \\
\hline Riboflavin (mg/d) & 1.1 & 1.4 & 1.6 \\
\hline Thiamine (mg/d) & 1.1 & 1.4 & 1.4 \\
\hline Vitamin B6 (mg/d) & 1.3 & 1.9 & 2 \\
\hline Vitamin B12 $(\mu \mathrm{g} / \mathrm{d})$ & 2.4 & 2.6 & 2.8 \\
\hline Vitamin C (mg/d) & 75 & 85 & 120 \\
\hline Calcium (mg/d) & 1000 & 1000 & 1000 \\
\hline Iron (mg/d) & 8 & 27 & 9 \\
\hline $\begin{array}{l}\text { Phosphorus } \\
(\mathrm{mg} / \mathrm{d})\end{array}$ & 700 & 700 & 700 \\
\hline Selenium $(\mu \mathrm{g} / \mathrm{d})$ & 55 & 60 & 70 \\
\hline Zinc (mg/d) & 8 & 11 & 12 \\
\hline
\end{tabular}

\section{Material and methods}

Following review of the PubMed database and the Guidelines of the Portuguese Directorate-General of Health (DGS) ${ }^{3}$, nutrients whose needs are increased during pregnancy were identified, and the Food Nutritional Composition Table of the National Institute of Health Doctor Ricardo Jorge ${ }^{30}$, placed in Portugal, was used to identify the ingredients richest in each. Lastly, cereal bars were created according to the increase in caloric intake recommended during pregnancy ${ }^{3}$.

The three cereal bars have an identical base of ingredients consisting of oat flakes, wheat flakes, honey and banana.

Oat (Avena sativa L.) was one of the ingredients selected because of its nutritional richness: it is the richest cereal in soluble fibres, additionally it is composed of beta-glucans, polyphenols, proteins and vitamins ${ }^{32}$. In terms of vitamins, oats contain: vitamin A: 0.862 $\mathrm{mg} / 100 \mathrm{~g}$, vitamin B6: $56 \mathrm{nmol} / \mathrm{g}$, among others, and at least their needs are increased during pregnancy ${ }^{3}$. Thus, oat consumption is beneficial during pregnancy as there is an increased need for fiber ${ }^{3}$. Due to its satiating effect ${ }^{32}$, it prevents an exaggerated weight increase in pregnancy. Moreover, the starch present can be used as a thickening agent ${ }^{32,33}$, which allows oats to be used
Tabela 1 - Recomendações Diárias de Micronutrientes para mulheres adultas2,3

\begin{tabular}{|c|c|c|c|}
\hline Nutriente & Não Grávida & Grávida $^{a}$ & Lactentes ${ }^{\mathrm{a}}$ \\
\hline Energia (kcal) & 2403 & $\begin{array}{l}2^{\circ} \text { Trimestre }-2743 \\
3^{\circ} \text { Trimestre - } 2855\end{array}$ & 2698 \\
\hline Proteína (g/kg/d) & 0,8 & 1,1 & 1,1 \\
\hline $\begin{array}{l}\text { Hidratos de carbono } \\
(\mathrm{g} / \mathrm{d})\end{array}$ & 130 & 175 & 210 \\
\hline Fibra total & 25 & 28 & 29 \\
\hline Ácido Linoleico (g/d) & 12 & 13 & 13 \\
\hline $\begin{array}{l}\text { Ácido alfa-Linolénico } \\
\text { (g/d) }\end{array}$ & 12 & 13 & 13 \\
\hline Ácido fólico & 400 & 600 & 500 \\
\hline Iodo (g) & 150 & 175 & 200 \\
\hline Magnésio (mg) & 320 & 350 & 310 \\
\hline Vitamina A $(\mu \mathrm{g} / \mathrm{d})$ & 700 & 770 & 1300 \\
\hline Vitamina D $(\mu \mathrm{g} / \mathrm{d})$ & 5 & 15 & 15 \\
\hline Vitamina E (mg/d) & 15 & 15 & 19 \\
\hline Vitamina $\mathrm{K}(\mu \mathrm{g} / \mathrm{d})$ & 90 & 90 & 90 \\
\hline Folato $(\mu \mathrm{g} / \mathrm{d})$ & 400 & 600 & 500 \\
\hline Niacina $(\mathrm{mg} / \mathrm{d})$ & 14 & 18 & 17 \\
\hline Riboflavina (mg/d) & 1,1 & 1,4 & 1,6 \\
\hline Tiamina (mg/d) & 1,1 & 1,4 & 1,4 \\
\hline Vitamina B6 (mg/d) & 1,3 & 1,9 & 2 \\
\hline Vitamina B12 $(\mu \mathrm{g} / \mathrm{d})$ & 2,4 & 2,6 & 2,8 \\
\hline Vitamina C (mg/d) & 75 & 85 & 120 \\
\hline Cálcio (mg/d) & 1000 & 1000 & 1000 \\
\hline Ferro (mg/d) & 8 & 27 & 9 \\
\hline Fósforo (mg/d) & 700 & 700 & 700 \\
\hline Selénio $(\mu \mathrm{g} / \mathrm{d})$ & 55 & 60 & 70 \\
\hline Zinco (mg/d) & 8 & 11 & 12 \\
\hline
\end{tabular}

\section{Material e Métodos}

Na sequência da revisão da base de dados Pubmed, nas Diretrizes da Direção-Geral de Saúde (DGS) ${ }^{3}$ foram identificados nutrientes cujas necessidades encontram-se aumentadas no decorrer da gravidez, e a Tabela de Composição Nutricional do Instituto Nacional de Saúde, Doutor Ricardo Jorge ${ }^{30}$, situado em Portugal, foi utilizada para identificar os alimentos mais ricos em cada nutriente. Por fim, as barritas foram criadas de acordo com o aumento da ingestão calórica recomendada ao longo da gravidez ${ }^{3}$.

As três barritas têm uma base de ingredientes idêntica composta por flocos de aveia, flocos de trigo, mel e banana.

A aveia (Avena sativa L.) foi um dos ingredientes selecionados devido à sua riqueza nutricional: trata-se do cereal mais rico em fibras solúveis; é composto ainda por beta-glucanos, polifenóis, proteínas e vitaminas ${ }^{32}$. Em termos vitamínicos, a aveia contém: vitamina A: $0.862 \mathrm{mg} / 100 \mathrm{~g}$, Vitamina B6: $56 \mathrm{nmol} / \mathrm{g}$, entre outras, sendo que pelo menos o aporte destas está aumentado durante a gravidez ${ }^{3}$. Desta forma, o consumo de aveia é benéfico durante a gravidez pois há um aumento da necessidade de fibras ${ }^{3}$. Devido ao seu efeito sacian$t^{32}$, previne o aumento exagerado de peso na gravidez. 
as an aggregator and unifying agent in the cereal bars, thus improving their organoleptic characteristics.

Wheat flakes were selected because of their richness in folic $\operatorname{acid}^{30}$, which allows to reduce neural tube malformations ${ }^{12,34}$ and preeclampsia ${ }^{35}$. In addition, wheat consumption during pregnancy, especially during the second trimester, is associated with a reduction in the occurrence of allergies and asthma in children ${ }^{36}$. Honey was used primarily because it is a natural sweetener $^{37}$. No type of artificial sweetener was used, since its use in pregnant women should be done with caution ${ }^{38}$. A possible variant for the bars created in this study would be the use of Stevia, a non-caloric natural sweetener, not metabolized by the body, with sweetening power 300 times higher than sucrose. Its discovery dates back to 1900 and has been used because of its antihyperglycemic ${ }^{39}$ and antihypertensive effects ${ }^{40}$. Scientific evidence indicates that there is no harm to its intake during pregnancy in animals ${ }^{41}$. However, there are no studies on its use during pregnancy in humans, therefore it was not used as a sweetening agent in the bars ${ }^{40}$. With a similar objective, banana was used because it is one of the richest fruits in magnesium, a mineral whose needs are increased in pregnancy ${ }^{3}$ (Table 1$)$. In addition, fruit consumption during pregnancy, without being in excess ${ }^{42}$, is associated with better cognitive development of the child ${ }^{43}$.

All bars have the above-mentioned ingredients as their basis. However, each one has other ingredients that are designed for appropriate nutritional support for each trimester of pregnancy. Blueberries were added to the cereal bar of the first trimester, being a fruit with a rich composition in vitamins ( $\mathrm{A}, \mathrm{B}, \mathrm{C}$ and $\mathrm{K}$ ), folates, potassium, magnesium, iron, among others ${ }^{44}$. Thus, blueberries increase the contribution of these nutrients, whose importance has been mentioned previously. Being a low-calorie fruit, it seems to be a useful ingredient in the first trimester bar as an increase in caloric intake is not required ${ }^{3}$.

The second trimester bar, in addition to the base ingredients, included almonds and cashews. During the second trimester, iron supplementation is recommended; hence the added ingredients are rich in this nutrient ${ }^{3}$. It is important to note that iron may be present in foods in two distinct ways: heme iron and nonheme iron. The heme iron, present mainly in products of animal origin, is easily absorbed by humans, while non-heme iron is found in products of plant origin and fortified foods and has a reduced absorption ${ }^{45,46}$.

Almonds were used because of their richness in folate ${ }^{47}$, magnesium $(250 \mathrm{mg} / 100 \mathrm{~g})$ and zinc $(3.1 \mathrm{mg} / 100 \mathrm{~g})$, whose needs are increased in pregnancy ${ }^{3}$. In addition, cashew nuts were used, which is
Além disso, o amido presente na aveia, pode ser usado como agente espessante $\mathrm{e}^{32,33} \mathrm{o}$ que permite, ser utilizado como agente agregador e unificador nas barritas, melhorando assim as suas características organoléticas.

Os flocos de trigo foram selecionados devido à sua riqueza em ácido fólico ${ }^{30}$, o qual permite reduzir mal-formações ao nível do tubo neural ${ }^{12,34} \mathrm{e}$ de pré-eclâmpsia ${ }^{35}$. Além disso, o consumo de trigo durante a gravidez, sobretudo durante o segundo trimestre, está associado a uma redução da ocorrência de alergias e asma nas crianças $^{36}$.

O mel foi utilizado principalmente devido a ser um adoçante natural ${ }^{37}$. Não se usou nenhum tipo de adoçante artificial, pois o seu uso em grávidas deve ser feito com precaução ${ }^{38}$.

Uma possível variante em relação às barritas criadas neste estudo seria a utilização de Stevia, um adoçante natural, não calórico, não metabolizado pelo organismo, cujo poder adoçante é 300 vezes superior ao da sacarose. A sua descoberta remonta a 1900 e tem sido utilizado devido aos seus efeitos anti-hiperglicimiantes ${ }^{39}$ e anti-hipertensivos ${ }^{40}$. A evidência científica indica que não existem malefícios da sua ingestão durante a gravidez em animais ${ }^{41}$. Todavia, não existem estudos quanto ao seu uso durante a gestação em humanos razão pela qual não foi utilizada como agente adoçante nas barri$\operatorname{tas}^{40}$.

Com um objetivo semelhante foi utilizada banana, pois é uma das frutas com maior riqueza em magnésio, mineral cujas necessidades estão aumentadas na gravidez ${ }^{3}$ (Table 1). Além de que o consumo de fruta durante a gravidez, sem ser em excesso ${ }^{42}$ está associado a um melhor desenvolvimento cognitivo da criança ${ }^{43}$.

Todas as barritas têm na sua constituição os ingredientes supracitados como base. No entanto, cada uma tem outros ingredientes que foram selecionados para um aporte nutricional adequado a cada trimestre da gravidez.

À barrita do primeiro trimestre foram acrescentados mirtilos, por serem uma fruta com uma composição rica em vitaminas (A, B, C e K), folatos, potássio, magnésio, ferro, entre outros ${ }^{44}$. Assim, os mirtilos permitem aumentar o aporte destes nutrientes cuja importância foi referida anteriormente. Tratando-se de uma fruta pouco calórica, parece ser um ingrediente útil na barrita do primeiro trimestre uma vez que nesta fase não é necessário que exista aumento da ingestão calórica ${ }^{3}$.

A barrita do segundo trimestre, além dos ingredientes-base, incluía amêndoas e cajus. Durante o segundo trimestre, é recomendada suplementação com ferro, daí que os ingredientes acrescentados sejam ricos neste nutriente ${ }^{3}$. É importante realçar que o ferro pode estar presente nos alimentos de duas formas distintas: ferro 
one of the richest fruits in iron $(6.8 \mathrm{mg} / 100 \mathrm{~g})^{30}$, containing significant amounts of fiber, unsaturated fat, vitamins and amino $\operatorname{acids}^{48}$. There are other alternatives to cashews, such as peanuts or pine nuts. Peanuts would be a good choice due to their nutritional composition including iron, zinc, choline ${ }^{49}$, proteins, fibers, polyphenols, antioxidants, vitamins and minerals. It has recently been shown that peanuts also provide resveratrol, phenolic compounds, flavonoids, phytosterols and even Coenzyme Q1050. The advantage of using pine nuts would be their nutritional composition rich in iron ${ }^{32}$, copper, magnesium, manganese, phosphorus and zinc ${ }^{51}$. However, recent studies $^{45,49}$ indicate that both peanuts and pine nuts contain anti-thyroid components and may interfere with iodine uptake. Although this is not a major problem if iodine intake is sufficient, as this mineral is of particular relevance during this stage of pregnancy, it has been found to be better to use another ingredient. The final cereal bar was designed for the third trimester. This phase is equal to the previous one in terms of supplementation ${ }^{18}$, however, there is an increase in caloric needs ${ }^{18}$. Thus more caloric ingredients were sought for use in the cereal bars.

It was decided to add walnuts because of their caloric density $^{32,49}$. Walnuts are a dry fruit rich in magnesium ${ }^{52}$ and omega-3, with potential beneficial effects on blood glucose and blood pressure ${ }^{53}$ promoting the prevention of preeclampsia ${ }^{3}$.

Dates were also used because of their preventive effect of anemia, nausea, blood pressure control, glycemia and improved function of the immune system ${ }^{54}$. In spite of being known as a very beneficial fruit, dates were only used in the cereal bar designed for the third trimester as their consumption in the final stage of pregnancy seems to have beneficial effects at childbirth. In fact, although the effect is not yet fully defined, it appears that it consumption of dates during the third trimester helps to increase the likelihood of vaginal delivery and reduces the need of induction ${ }^{55,56}$ The recommended supplementation recommended for pregnant women without previous pathologies and in Portugal were taken into account in the formulation of these bars, in particular for the supplementation of iodine (150-200 $\mu \mathrm{g}$ /day in the form of potassium iodide) and folic acid throughout pregnancy and iron in the second and third trimesters $(27 \mathrm{mg} / \text { day })^{10}$.

The mode of preparation of these bars was as follows - peel and crush the banana to a pulp (with the help of a mortar); add oats and wheat flakes, honey and other ingredients (first trimester: blueberries, second trimester: crushed almonds and cashews (crushed in a mixer); third trimester: dates and crushed walnuts) and fold to- heme e fero não heme. $\mathrm{O}$ ferro heme, presente maioritariamente em produtos de origem animal, é facilmente absorvido pelos humanos, enquanto que o ferro não heme, encontra-se em produtos de origem vegetal e alimentos fortificados e tem uma absorção mais reduzida $^{45,46}$.

As amêndoas foram utilizadas devido à sua riqueza em folatos ${ }^{47}$, magnésio $(250 \mathrm{mg} / 100 \mathrm{~g})$ e zinco $(3.1 \mathrm{mg} / 100 \mathrm{~g})$, cujas necessidades estão aumentados na gravidez ${ }^{3}$.

Foi ainda utilizado caju, um dos frutos secos mais rico em ferro $(6.8 \mathrm{mg} / 100 \mathrm{~g})^{30}$, contendo ainda quantidades significativas de fibra, gordura insaturada, vitaminas e aminoácidos ${ }^{48}$.

Existem outras alternativas aos cajus, tais como amendoins ou pinhões. Os amendoins seriam uma boa opção pela sua composição nutricional, contendo ferro, zinco, colina ${ }^{49}$, proteínas, fibras, polifenóis, antioxidantes, vitaminas e minerais. Recentemente verificou-se que os amendoins fornecem ainda resveratrol, compostos fenólicos, flavonoides, fitosteróis e ainda Coenzima Q10 ${ }^{50}$. A mais valia da utilização de pinhões seria a sua composição nutricional rica em ferro $^{32}$, cobre, magnésio, manganês, fósforo e zinco ${ }^{51}$. Contudo, estudos recentes indicam que, tanto os amendoins como os pinhões contêm substâncias anti-tiroideias, poderão interferir com a absorção de iodo. Apesar de isto não representar um problema de maior desde que a ingestão de iodo seja suficiente ${ }^{45,49}$, este mineral tem uma relevância especial nesta fase da gravidez pelo que se optou pela utilização de outro ingrediente.

A última barrita foi delineada para o terceiro trimestre. Esta fase é igual ao trimestre anterior em termos de suplementação ${ }^{18}$, todavia, há um aumento das necessidades calóricas ${ }^{18}$. Assim procuraram-se ingredientes mais calóricos que pudessem ser utilizados nas barritas.

Optou-se por adicionar nozes devido à sua densidade calórica $^{32,49}$. A noz é muito rica em magnésio ${ }^{52}$ e ómega-3, com potenciais efeitos benéficos no nível de glicose e nos valores de pressão arterial $^{53}$ contribuindo para a prevenção de pré-eclâmpsia ${ }^{3}$.

Também foram utilizadas tâmaras devido ao seu efeito preventivo de anemia, náuseas, controlo da tensão arterial, glicemia além de melhorar o funcionamento do sistema imunitário ${ }^{54}$. Apesar de ser um fruto conhecido por ser benéfico, as tâmaras foram usadas pois o seu consumo no final da gravidez parece ter efeitos benéficos no parto. De facto, apesar de o efeito ainda não estar completamente definido, parece que o consumo de tâmaras no último trimestre ajuda a aumentar a probabilidade de parto vaginal e a reduzir a necessidade da sua indução do mesmo ${ }^{55,56}$.

A suplementação recomendada para grávidas sem pa- 
gether; transfer the mixture into a rectangular tin lined with grease proof paper and spread it evenly; bake for 10 minutes in a preheated oven at $150^{\circ} \mathrm{C}$; remove from oven and allow to cool; cut the baked product into small rectangles, about 3,7 inches of length. The bars were then stored at room temperature (approximately $11^{\circ} \mathrm{C}$ ) for about 12 hours after which they were tasted by the panel.

The following quantities in the preparation of the bars: First trimester cereal bar $-10 \mathrm{~g}$ of oat flakes, $8 \mathrm{~g}$ of dried blueberries, $1 \mathrm{~g}$ of honey, $8 \mathrm{~g}$ of wheat flakes, $11 \mathrm{~g}$ of banana;

Second trimester cereal bar $-10 \mathrm{~g}$ of oat flakes, $8 \mathrm{~g}$ of almonds, $1 \mathrm{~g}$ of honey, $8 \mathrm{~g}$ of wheat flakes, $6 \mathrm{~g}$ of cashew, $11 \mathrm{~g}$ of banana;

Third trimester cereal bar $-10 \mathrm{~g}$ of oat flakes, $10 \mathrm{~g}$ of walnuts, $1 \mathrm{~g}$ of honey, $8 \mathrm{~g}$ of wheat flakes, $8 \mathrm{~g}$ of pitted dates, $11 \mathrm{~g}$ of banana.

\section{Results}

After nutritional design and according to the indicated preparations, three different types of cereal bars were obtained, each one indicated for a specific trimester of pregnancy. To establish the nutritional analysis of the bars, calculations were made based on the data available in the database of the National Institute of Health Ricardo Jorge $^{30}$ and in the case of ingredients that did not have that information available, the values of the table of the United States Department of Agriculture ${ }^{31}$ (Table 2). tologias prévias e em Portugal foi tida em conta na formulação destas barritas, nomeadamente no que respeita à suplementação de iodo $(150 \mathrm{a} 200 \mu \mathrm{g} / \mathrm{dia}$ sob a forma de iodeto de potássio) e de ácido fólico ao longo de toda a gravidez e de ferro nos segundo e terceiro trimestres $(27 \mathrm{mg} / \mathrm{dia})^{10}$.

O modo de preparação e confeção destas barritas foi bastante simples: descascar e esmagar a banana (com o auxílio de um almofariz) até formar uma polme; adicionar os flocos de aveia e de trigo, o mel e outros ingredientes ( $1^{\circ}$ Trimestre: mirtilos; $2^{\circ}$ Trimestre: amêndoas e cajus triturados (numa misturadora); $3^{\circ}$ Trimestre: tâmaras e nozes trituradas) e envolver no preparado; deitar este numa forma retangular sobre papel vegetal e espalhar; levar ao forno previamente aquecido durante 10 minutos a $150^{\circ} \mathrm{C}$; retirar do forno e deixar arrefecer. Cortar o preparado em pequenos rectângulos com cerca de $9 \mathrm{~cm}$ de comprimento. As barritas foram depois armazenadas à temperatura ambiente (aproximadamente $11^{\circ} \mathrm{C}$ ) durante $12 \mathrm{~h}$, após as quais, foram consumidas pelo painel.

Na preparação e confeção das barritas foram utilizadas as seguintes quantidades:

Barrita do primeiro trimestre - $10 \mathrm{~g}$ de flocos de aveia, $8 \mathrm{~g}$ de mirtilos secos, $1 \mathrm{~g}$ de mel, $8 \mathrm{~g}$ de flocos de trigo, $11 \mathrm{~g}$ de banana;

Barrita do segundo trimestre - $10 \mathrm{~g}$ de flocos de aveia, $8 \mathrm{~g}$ de amêndoas, $1 \mathrm{~g}$ de mel, $8 \mathrm{~g}$ de flocos de trigo, $6 \mathrm{~g}$ de caju, 11g de banana;

Barrita do terceiro trimestre - $10 \mathrm{~g}$ de flocos de aveia, $10 \mathrm{~g}$ de miolo de noz, $1 \mathrm{~g}$ de mel, $8 \mathrm{~g}$ de flocos de trigo, $8 \mathrm{~g}$ de tâmaras sem caroço, $11 \mathrm{~g}$ de banana.

\section{Resultados}

Após o planeamento em temos nutricionais e de acordo com as preparações indicadas, obtiveram-se três tipos diferentes de barritas, indicados para cada um dos trimestres da gravidez. Para se proceder à análise nutricional das barritas, efetuaram-se os cálculos com base nos dados disponíveis na base de dados do Instituto Nacional de Saúde Ricardo Jorge ${ }^{30}$ e no caso de ingredientes que não constavam desta, recorreu-se aos valores da tabela do United States Department ofAgriculture ${ }^{31}$ (Tabela 2). 
Table 2 - Cereal Bars Nutritional Information

\begin{tabular}{|c|c|c|c|c|c|c|c|c|c|c|c|c|c|c|c|c|c|c|c|c|c|c|c|c|c|c|c|}
\hline \multirow[b]{2}{*}{ Trimester } & \multicolumn{3}{|c|}{$\begin{array}{l}\text { Quantity } \\
\text { (g) }\end{array}$} & \multicolumn{3}{|c|}{ Energy (kcal) } & \multicolumn{3}{|c|}{ Lipids (g) } & \multicolumn{3}{|c|}{\begin{tabular}{|c|} 
Carbohydrates \\
(g)
\end{tabular}} & \multicolumn{3}{|c|}{ Protein (g) } & \multicolumn{3}{|c|}{ Iron (mg) } & \multicolumn{3}{|c|}{ Vit B6 (mg) } & \multicolumn{3}{|c|}{ Folate ( $\mu \mathrm{g})$} & \multicolumn{3}{|c|}{ Zinc(mg) } \\
\hline & $1^{\text {st }}$ & $2^{\text {nd }}$ & $3^{\text {rd }}$ & $1^{\mathrm{st}}$ & $2^{\text {nd }}$ & $3^{\text {rd }}$ & $1^{\mathrm{st}}$ & $2^{\text {nd }}$ & $3^{\text {rd }}$ & $1^{\text {st }}$ & $2^{\text {nd }}$ & $3^{\text {rd }}$ & $1^{\mathrm{st}}$ & $2^{\text {nd }}$ & $3^{\text {rd }}$ & $1^{\mathrm{st}}$ & $2^{\text {nd }}$ & $3^{\text {rd }}$ & $1^{\mathrm{st}}$ & $2^{\text {nd }}$ & $3^{\text {rd }}$ & $1^{\mathrm{st}}$ & $2^{\text {nd }}$ & $3^{\text {rd }}$ & $1^{\text {st }}$ & $2^{\text {nd }}$ & $3^{\text {rd }}$ \\
\hline Oat flakes & 10 & 10 & 10 & 36.6 & 36.6 & 36,6 & 0.58 & 0.58 & 0.58 & 6.2 & 6.2 & 6.2 & 1.4 & 1.4 & 1.4 & $\mid 0.1$ & 0.1 & 0.1 & \begin{tabular}{l|l}
0.02 \\
\end{tabular} & 0.02 & 0.02 & 5.6 & 5.6 & 5.6 & 0.5 & 0.5 & 0.5 \\
\hline Blueberries & 8 & -- & -- & 3.42 & -- & -- & 0.026 & -- & -- & 1.16 & -- & -- & 0.06 & -- & -- & $\begin{array}{c}0.02 \\
2\end{array}$ & -- & -- & 0.004 & -- & -- & 0.48 & -- & -- & \begin{tabular}{|l|}
0.01 \\
\end{tabular} & -- & -- \\
\hline Honey & 1 & 1 & 1 & 3.14 & 3.14 & 3,14 & 0 & 0 & 0 & 0.78 & 0.78 & 0.78 & 0.005 & 0.005 & 0.005 & $\begin{array}{c}0.00 \\
4\end{array}$ & 0.004 & 0.004 & 0.002 & 0.002 & 0.002 & 0 & 0 & 0 & 0.009 & 0.009 & 0.009 \\
\hline $\begin{array}{l}\text { Wheat } \\
\text { flakes } \\
\end{array}$ & 8 & 8 & 8 & 27.52 & 27.52 & $\begin{array}{c}27,5 \\
2\end{array}$ & 0.09 & 0.09 & 0.09 & 5.9 & 5.9 & 5.9 & 0.62 & \begin{tabular}{|l|}
0.62 \\
\end{tabular} & \begin{tabular}{|l|}
0.62 \\
\end{tabular} & 0.09 & 0.09 & 0.09 & 0.01 & 0.01 & 0.01 & 1.8 & 1.8 & 1.8 & \begin{tabular}{|l|}
0.07 \\
\end{tabular} & 0.07 & 0.07 \\
\hline$\overline{\text { Banana }}$ & 11 & 11 & 11 & 11.44 & 11.44 & $\begin{array}{c}11,4 \\
4\end{array}$ & 0.89 & 0.89 & 0.89 & 2.4 & 2.4 & 2.4 & 0.18 & 0.18 & 0.18 & 0.04 & 0.04 & 0.04 & 0.03 & 0.03 & 0.03 & 1.54 & 1.54 & 1.54 & 0.02 & 0.02 & 0.02 \\
\hline Almonds & -- & 8 & -- & -- & 52 & -- & -- & 4.5 & -- & -- & 0.57 & -- & -- & 1.7 & -- & -- & 0.33 & -- & -- & 0.007 & -- & -- & 3 & -- & -- & 0.26 & -- \\
\hline \begin{tabular}{|l} 
Cashew \\
\end{tabular} & -- & 6 & -- & -- & 36.8 & -- & -- & 3 & -- & -- & 1.16 & -- & -- & \begin{tabular}{|l|}
1.18 \\
\end{tabular} & -- & -- & 0.34 & -- & -- & 0.025 & -- & -- & 4.8 & -- & -- & 0.34 & -- \\
\hline Nut & -- & -- & 10 & -- & -- & 69,9 & -- & -- & 6.75 & -- & -- & 0.36 & -- & -- & 1.3 & -- & -- & 0.26 & -- & -- & 0.067 & -- & -- & 6.6 & -- & -- & 0.27 \\
\hline Dates & -- & -- & 8 & -- & -- & 23,8 & -- & -- & 0.02 & -- & -- & 5.4 & -- & -- & 0.2 & -- & -- & 0.1 & -- & -- & 0.02 & -- & -- & 1 & -- & -- & 0.02 \\
\hline Total & 39 & 45 & 48 & 82.12 & 167.5 & 17.4 & 1.666 & 9.14 & 7.06 & 16.44 & 17.01 & 21.04 & 2.265 & 5.085 & 3.705 & $\begin{array}{c}0.25 \\
6 \\
\end{array}$ & 0.904 & 0.594 & 0.066 & 0.094 & 0.149 & 9.42 & 16.74 & 16.54 & \begin{tabular}{|l|}
0.609 \\
\end{tabular} & 1.199 & 0.889 \\
\hline$\%$ RDD & -- & -- & -- & 3.42 & 6.11 & 6.04 & * & $*$ & $*$ & 12.65 & 9.72 & 10.2 & ** & $* *$ & $* *$ & 3.2 & 3.35 & 6.6 & 5.08 & 15.50 & 7.45 & 2.36 & 2.79 & 3.31 & \begin{tabular}{|l|}
7.61 \\
\end{tabular} & 10.9 & 7.41 \\
\hline
\end{tabular}

Note - In this work, three bars of cereal were prepared, each one directed to a specific quarter, this table has the nutritional information of a bar of the third quarter.

* - Value not possible to determine due to lack of data; ** - Recommended Daily Doses varies according to the woman's weight.

Tabela 2 - Informação Nutricional das barritas

\begin{tabular}{|c|c|c|c|c|c|c|c|c|c|c|c|c|c|c|c|c|c|c|c|c|c|c|c|c|c|c|c|}
\hline \multirow[b]{2}{*}{ Trimestre } & \multicolumn{3}{|c|}{$\begin{array}{l}\text { Quantidade } \\
\text { (g) }\end{array}$} & \multicolumn{3}{|c|}{ Energia (kcal) } & \multicolumn{3}{|c|}{ Lípidos (g) } & \multicolumn{3}{|c|}{$\begin{array}{l}\text { Hidratos de } \\
\text { Carbono (g) }\end{array}$} & \multicolumn{3}{|c|}{ Proteína (g) } & \multicolumn{3}{|c|}{ Ferro (mg) } & \multicolumn{3}{|c|}{ Vit B6 (mg) } & \multicolumn{3}{|c|}{ Folatos ( $\mu \mathrm{g})$} & \multicolumn{3}{|c|}{ Zinco(mg) } \\
\hline & $1^{\circ}$ & $2^{\circ}$ & $3^{\circ}$ & $1^{\circ}$ & $2^{\circ}$ & $3^{\circ}$ & $1^{\circ}$ & $2^{\circ}$ & $3^{\circ}$ & $1^{\circ}$ & $2^{\circ}$ & $3^{\circ}$ & $1^{\circ}$ & $2^{\circ}$ & $3^{\circ}$ & $1^{\circ}$ & $2^{\circ}$ & $3^{\circ}$ & $1^{\circ}$ & $2^{\circ}$ & $3^{\circ}$ & $1^{\circ}$ & $2^{\circ}$ & $3^{\circ}$ & $1^{\circ}$ & $2^{\circ}$ & $3^{\circ}$ \\
\hline $\begin{array}{l}\text { Flocos de } \\
\text { Aveia }\end{array}$ & 10 & 10 & 10 & 36,6 & 36,6 & 36,6 & 0,58 & 0,58 & $\begin{array}{l}0,58 \\
\end{array}$ & 6,2 & 6,2 & 6,2 & 1,4 & 1,4 & 1,4 & \begin{tabular}{|l|}
0,1 \\
\end{tabular} & 0,1 & 0,1 & 0,02 & 0,02 & 0,02 & 5,6 & 5,6 & 5,6 & 0,5 & 0,5 & 0,5 \\
\hline $\begin{array}{l}\text { Mirtilos } \\
\text { secos }\end{array}$ & 8 & -- & -- & 3,42 & -- & -- & 0,026 & -- & -- & 1,16 & -- & -- & 0,06 & -- & -- & $\begin{array}{c}0,02 \\
2\end{array}$ & -- & -- & 0,004 & -- & -- & 0,48 & -- & -- & 0,01 & -- & -- \\
\hline $\begin{array}{l}\text { Mel } \\
\end{array}$ & 1 & 1 & 1 & 3,14 & 3,14 & 3,14 & 0 & 0 & 0 & 0,78 & 0,78 & 0,78 & 0,005 & $\begin{array}{c}0,00 \\
5\end{array}$ & 0,005 & $\begin{array}{c}0,00 \\
4\end{array}$ & 0,004 & 0,004 & 0,002 & 0,002 & 0,002 & 0 & 0 & 0 & 0,009 & 0,009 & 0,009 \\
\hline $\begin{array}{l}\text { Flocos de } \\
\text { Trigo }\end{array}$ & 8 & 8 & 8 & 27,52 & 27,52 & $\begin{array}{c}27,5 \\
2\end{array}$ & 0,09 & 0,09 & 0,09 & 5,9 & 5,9 & 5,9 & 0,62 & 0,62 & 0,62 & 0,09 & 0,09 & 0,09 & 0,01 & 0,01 & 0,01 & 1,8 & 1,8 & 1,8 & 0,07 & 0,07 & 0,07 \\
\hline Banana & 11 & 11 & 11 & 11,44 & 11,44 & $\begin{array}{c}11,4 \\
4\end{array}$ & 0,89 & 0,89 & 0,89 & 2,4 & 2,4 & 2,4 & 0,18 & 0,18 & 0,18 & 0,04 & 0,04 & 0,04 & 0,03 & 0,03 & 0,03 & 1,54 & 1,54 & 1,54 & 0,02 & 0,02 & 0,02 \\
\hline Amêndoas & -- & 8 & -- & -- & 52 & -- & -- & 4,5 & -- & -- & 0,57 & -- & -- & 1,7 & -- & -- & 0,33 & -- & -- & 0,007 & -- & -- & 3 & -- & -- & 0,26 & -- \\
\hline Caju & -- & 6 & -- & -- & 36,8 & -- & -- & 3 & -- & -- & 1,16 & -- & -- & 1,18 & -- & -- & 0,34 & -- & -- & 0,025 & -- & -- & 4,8 & -- & -- & 0,34 & -- \\
\hline Miolo de $\mathrm{Noz}$ & -- & -- & 10 & -- & -- & 69,9 & -- & -- & 6,75 & -- & -- & 0,36 & -- & -- & 1,3 & -- & -- & 0,26 & -- & -- & 0,067 & -- & -- & 6,6 & -- & -- & 0,27 \\
\hline $\begin{array}{l}\text { Tâmaras sem } \\
\text { caroço }\end{array}$ & -- & -- & 8 & -- & -- & 23,8 & -- & -- & 0,02 & -- & -- & 5,4 & -- & -- & 0,2 & -- & -- & 0,1 & -- & -- & 0,02 & -- & -- & 1 & -- & -- & 0,02 \\
\hline Total & 39 & 45 & 48 & 82,12 & 167,5 & $\begin{array}{c}172 \\
4\end{array}$ & 1,666 & 9,14 & 7,06 & 16,44 & 17,01 & 21,04 & 2,265 & $\begin{array}{c}5,08 \\
5\end{array}$ & 3,705 & $\begin{array}{c}0,25 \\
6\end{array}$ & 0,904 & 0,594 & 0,066 & 0,094 & 0,149 & 9,42 & 16,74 & 16,54 & 0,609 & 1,199 & 0,889 \\
\hline$\%$ DDR & -- & -- & -- & 3,42 & 6,11 & 6,04 & $*$ & $*$ & $*$ & 12,65 & 9,72 & 10,2 & ** & ** & $* *$ & 3,2 & 3,35 & 6,6 & 5,08 & 15,50 & 7,45 & 2,36 & 2,79 & 3,31 & 7,61 & 10,9 & 7,41 \\
\hline
\end{tabular}

Nota Explicativa - Neste trabalho foram elaboradas três barritas de cerais, cada uma direccionada a um trimestre especifico, esta tabela tem a informação nutricional de uma barrita do terceiro trimestre.

* - Valor não possível de determinar por falta de dados; ** - Dose Diária Recomendada varia consoante o peso da mulher

\section{Discussion}

Many pregnant women are concerned about nutrition ${ }^{57}$. However, the amount of (sometimes contradictory) information available may contribute to decrease the adherence to healthy eating by the pregnant woman ${ }^{57}$. For the majority of pregnant women, the increase of energy needs may be suppressed by consuming one or two daily snacks ${ }^{58}$. In addition, it is important for pregnant women to have a nutritionally rich and balanced diet to help them maintain stable blood glucose levels even when they cannot have a break from work. Even in non-developed countries, the use of nutrient-dense

\section{Discussão}

Muitas grávidas preocupam-se com a nutrição ${ }^{57}$. Contudo, devido à quantidade de informação disponível (por vezes contraditória), esta pode contribuir para uma diminuição na adesão a uma alimentação saudável por parte da grávida ${ }^{57}$.

Para a maioria das grávidas, as necessidades energéticas acrescidas poderão ser suprimidas através do consumo de um ou dois snacks diários ${ }^{58}$. Além disso, é importante que as grávidas possam ter um alimento nutricionalmente rico e equilibrado que as ajude a manter estáveis os seus níveis de glicémia, mesmo durante períodos 
snacks makes helps to prevent the occurrence of some deficiencies ${ }^{59}$.

Although no scientific evidence has been published to identify the advantages of using cereal bars during pregnancy, it was found that their consumption at breakfast by the general population is associated with an improvement in mood and memory ${ }^{60}$. It was in this context that these three bars adapted to pregnancy were created.

During the selection phase of the ingredients, in addition to the nutritional information of the ingredients, more economical foods, such as oats or bananas, were also selected. However, some of the ingredients initially chosen to be integrated were eventually excluded as consequence of the scientific evidence mentioned above.

The cereal bars were planned to be consumed twice a day. Analyzing the nutritional results, we can verify that the bars are not very caloric: $82.12 \mathrm{kcal}, 167.5 \mathrm{kcal}$ and $172.4 \mathrm{kcal}$, respectively, thus the intake of two bars is equivalent to $6.84 \%, 12.22 \%$ and $12.08 \%$ of the daily caloric needs of the pregnant woman in each respective trimester. Therefore, the bars comply not only with the progressive caloric increase during pregnancy (Table 1), but also with regard to the fact that the greatest increase occurs between the first and second trimesters (Table 2).

This analysis has to take into account that the cereal bar is a single snack, belonging to an intermediate meal, and that therefore the objective was not that its consumption alone could reach the values of all the micronutrients whose daily needs are increased. However, it should be noticed that only natural ingredients were used in the preparation of these bars. The use of synthetic forms of the micronutrient components would certainly lead to much higher nutritional value. For example, the synthetic form of folic acid has a higher bioavailability than folate from food ${ }^{61}$.

It is important to mention that women who take supplementation, if the nutritional value becomes close enough to DRI, it could contribute to an overdose that could negatively impact pregnancy ${ }^{26,62,63}$.

Unfortunately, it was not possible to analyze the percentage of iodine DRI because bibliography consulted did not include information on this micronutrient ${ }^{2,3}$.

From the organoleptic point of view, the bars had a soft texture, were easy to chew, and had a pleasant scent in which the banana stood out slightly. A sensorial test was performed by six people, aged between 23 and 65 years, with four (non-pregnant) females and two males. Notwithstanding the fact that they are not design to replace a meal, these bars may be important tools to help motivate pregnant women to adopt a healthy diet, al- do dia em que os afazeres laborais dificultem paragens no trabalho. Mesmo em países em desenvolvimento, a utilização de snacks de elevada densidade nutricional, ajuda a prevenir algumas carências ${ }^{59}$.

Apesar de não ter sido encontrada nenhuma evidência científica publicada que identifique vantagens da utilização específica de barritas de cereais na gravidez, verificou-se que o seu consumo ao pequeno-almoço, na população em geral, está associado a uma melhoria em termos de humor e memória ${ }^{60}$. Foi pois neste contexto que foram criadas três barritas adaptadas à gravidez.

Durante a fase de seleção dos ingredientes, além de se ter em consideração a informação nutricional dos mesmos, foram também, dentro do possível, selecionados alimentos económicos como aveia ou banana. Todavia, alguns ingredientes, que inicialmente se considerou que iriam ser utilizados, acabaram por ser excluídos devido à evidência científica encontrada, como supracitado.

As barritas foram planeadas de modo a poderem ser consumidas duas vezes por dia. Ao analisarmos os resultados obtidos do ponto de vista nutricional, podemos verificar que estas não são muito calóricas: $82.12 \mathrm{kcal}$, $167.5 \mathrm{kcal}$ e $172.4 \mathrm{kcal}$, assim a ingestão de duas barritas corresponde a $6.84 \%, 12.22 \%$ e $12.08 \%$ das necessidades calóricas diárias da grávida em cada trimestre. Verifica-se portanto que as barritas estão de acordo, não só com o aumento calórico progressivo ao longo da gravidez (Tabela 1), como também respeitam o facto de o maior aumento ocorrer entre o primeiro e o segundo trimestres (Tabela2).

Nesta análise tem que se ter em conta que se trata de um único alimento pertencente a uma refeição intermédia, e que por isso mesmo, o objetivo não era que o seu consumo de forma isolada permitisse atingir os valores de todos os micronutrientes cujas necessidades diárias estão aumentadas. É ainda necessário realçar que apenas foram utilizados alimentos naturais na elaboração destas barritas, com o recurso à forma sintética de alguns micronutrientes obter-se-iam valores nutricionais bastante mais elevados. Por exemplo: a forma sintética do ácido fólico apresenta uma maior biodisponibilidade de folato existente nos alimentos ${ }^{61}$.

É importante mencionar que as mulheres fazem suplementação, se o valor nutricional se aproximasse bastante da DDR, contribuiria para que houvesse uma sobredosagem que poderia ter um impacto negativo na gravide $z^{26,62,63}$.

Infelizmente não foi possível analisar a percentagem da DDR de iodo porque as referências bibliográficas consultadas não tinham informação sobre este micronutriente ${ }^{2,3}$

Do ponto de vista organolético, as barritas apresentavam uma textura macia, eram de fácil mastigação e 
lowing not only the maintenance of a healthy weight, but also the prevention of nutritional deficiencies.

In order to confirm if there were similar products at the national level, on-line searches were carried out within supermarkets in Portugal ${ }^{64-67}$ and there was a considerable variety of the following types of cereal bars, including those for energy, with no added sugars, for children, protein-rich, gluten-free, fiber-rich and organic. However, there was evidence of an absence of cereal bars specifically for pregnant women, thus it was concluded that these bars would be an innovative product, since there seems to be nothing similar in the Portuguese market.

Within the industrial sector, the major innovations have been in terms of the formulation of ingredients and additives, transgenics, packaging and functional foods ${ }^{68}$. Although sales of traditional breakfast cereals are generally declining, cereal bars are on the rise because of their portability, the possibility of using various ingredients and their nutritional benefits ${ }^{69}$. In fact, there are several studies on changes in cereal bars through the use of green banana flour ${ }^{70}$, and high fiber content ${ }^{71,72}$. Thus, it is possible to verify the creation of these type of bars is logical, because they are a functional product, innovative not only in their combination of ingredients, but also by the target audience for which they are intended.

The main limitation of this study is the fact that these products have not yet been tested by a significant number of people. These tests will be important in order to allow possible minor adjustments in terms of organoleptic characteristics, thus increasing consumer satisfaction. Additionally, biochemical tests were not carried out to determine the nutritional composition of the cereal bars already made (since the vitamin content may be reduced after exposure to high temperatures), the water content, and the microbiological assessment. Concomitant, because these cereal bars have not yet been tested, by monitoring the evolution of weight and serological tests, their effectiveness has yet to be determined.

Based on the limitations described, it is suggested for future studies to analyze the effect of cereal bar consumption during pregnancy is analyzed. The results of the complete blood count each trimester may be used according to the recommendations of $\mathrm{DGS}^{73}$.

Likewise, with the execution of the fasting glucose test in the first trimester and the Oral Tolerance Test in the second trimester, it will be possible to verify if stable glycemic values were obtained through a polyfractionated alimentation such as the cereal bars designed for this study.

As part of further development of the bars, the addition apresentavam um odor agradável no qual a banana sobressaía ligeiramente. A prova sensorial foi realizada por seis pessoas, com idades compreendidas entre os 23 e os 65 anos, quatro do sexo feminino (não grávidas) e dois do sexo masculino.

Apesar destas barritas não terem sido delineadas para substituírem uma refeição, poderão constituir-se como ferramentas importantes na adesão a uma alimentação saudável por parte da grávida permitindo, não só a manutenção de um peso adequado, como também, a prevenção de carências nutricionais.

Para confirmar se existiam produtos semelhantes a nível nacional, realizaram-se pesquisas nos motores de busca de supermercados existentes em Portugal ${ }^{64-}$ ${ }^{-67}$ e verificou-se existir uma considerável variedade de barritas de cereais incluindo as energéticas, sem açúcares adicionados, dirigidas a crianças, com alto teor proteico, sem glúten, ricas em fibra e orgânicas. Todavia, constatou-se que existe uma ausência deste tipo de produtos dirigidos especificamente a grávidas, pelo que concluiu-se que estas barritas seriam um produto inovador, pois da pesquisa efetuada, não foi possível encontrar este tipo de produto no mercado português.

$\mathrm{Na}$ área da indústria as grandes inovações têm ocorrido maioritariamente em termos da formulação de ingredientes e aditivos, transgénicos, embalagens e alimentos funcionais ${ }^{68}$. Apesar de as vendas dos cereais de pequeno-almoço estarem genericamente em declínio, as barritas estão em ascensão, devido à sua portabilidade, à possibilidade da utilização de múltiplos ingredientes e aos respetivos benefícios nutricionais ${ }^{69}$. Na realidade, são vários os trabalhos existentes que são relativos a mudanças nas barritas, através da utilização de farinha de banana verde ${ }^{70}$ ou apresentando um teor elevado em fibras $^{71,72}$. Assim a criação deste tipo de barritas faz todo o sentido, pois trata-se de um produto funcional e inovador, não só na sua combinação de ingredientes, como também pelo público-alvo a que se destinam.

A principal limitação deste estudo é o facto deste produto ainda não ter sido testado por um número significativo de pessoas. Estas provas serão importantes para que seja possível proceder-se a eventuais pequenos ajustes em termos de características organoléticas, permitindo aumentar a satisfação dos consumidores. Além disso, não foram executados testes de natureza bioquímica para determinar: a composição nutricional das barritas já confecionadas (uma vez que o teor vitamínico poderá sofrer uma redução após exposição a temperaturas elevadas), o teor em água e uma avaliação do ponto de vista microbiológico. Concomitante, pelo facto de estas barritas não ainda terem sido testadas, o acompanhamento da evolução do peso e de exames serológicos comprovativos da sua eficácia ainda não 
of a microalgae should also be considered because it is an interesting food from the nutritional point of view, although the (nutritional) values change according to season, species and characteristics of the coastal environment where they develop ${ }^{74}$. Another limiting factor for the use of this type of food is the lack of knowledge of its bioavailability and the way in which its components are metabolized. In this study, the microalgae would be Spirulina because it contains a high percentage of vitamin B12 compounds, the most predominant of which is Pseudovitamin B12, which is not bioavailable to the human organism ${ }^{75}$.

\section{Conflict of interest}

The authors declare that there is no financial or personal relationship that can be understood as representing a potential conflict of interest. foram executados.

Com base nas limitações descritas, sugere-se para estudos futuros se possa analisar o efeito do consumo das barritas ao longo da gravidez. Poder-se-á utilizar os resultados do hemograma completo trimestral de acordo com as recomendações da DGS ${ }^{73}$.

Com as análises do segundo trimestre será possível verificar se, através de uma alimentação seriam obtidos valores de glicemia estáveis através de uma alimentação polifracionada, como as barritas projetadas neste estudo.

Para um maior desenvolvimento das barritas, a adição de uma microalga deveria ser considerada devido a ser um alimento interessante do ponto de vista nutricional, ainda que os valores (nutricionais) variem consoante: a sazonalidade, a espécie e as características do ambiente costeiro onde se desenvolvem ${ }^{74}$. Um outro fator limitante da utilização deste tipo de alimentos é o desconhecimento com exatidão da sua biodisponibilidade e da forma como se processa o metabolismo dos seus componentes $^{75}$.

\section{Conflito de interesse}

Os autores declaram não existirem quaisquer relações de natureza financeira ou pessoal que possam ser entendidas ou representarem um potencial conflito de interesses. 


\section{References/ Referências}

[1] Lebreiro AP. Especificidades nutricionais da gravidez. Faculdade de Ciências da Nutrição e Alimentação. 2005/2006. In: https://repositorio-aberto.up.pt/ bitstream/10216/54762/5/107070_06-28T_TL_01_P.pdf.

[2] Kominiarek MA. Nutrition Recommendations in Pregnancy and Lactation. MedClin N Am 2016; 100:1199-1215. Disponível em http://dx.doi. org/10.1016/j.mena.2016.06.004.

[3] Direção-Geral de Saúde. Alimentação e Nutrição na Gravidez. Lisboa: Programa Nacional para a Promoção da Alimentação Saudável 2014. ISBN 978972-675-221-9. In: http://www.alimentacaosaudavel.dgs.pt/activeapp/wp-content/files_mf/1444899925Alimentacaoenutricaonagravidez.pdf.

[4]Procter SB. Position of the Academy of Nutrition and Dietetics: Nutrition and Lifestyle for a Healthy Pregnancy Outcome. J Acad Nutr Diet. 2014 Jul;114(7):1099-103. In: http://jandonline.org/article/S2212-2672(14)00501-2/pdf

[5] Seely EW, Ecker J. Chronic hypertension in pregnancy. N Engl J Med. 2011; 365(5): 439-446. In: http://circ.ahajournals.org/content/129/11/1254

[6] Centers for Disease Control and Prevention. National Diabetes fact sheet: Gestational diabetes in the United States 2011. In: http://www.cdc.gov/diabetes/ pubs/estim ates11.htm.

[7] Sotres-Alvarez D, et al. Maternal Dietary Patterns are Associated With Risk of Neural Tube and Congenital Heart Defects. Am J Epidemiol2013; 177(11):1279-1288. In: http://aje.oxfordjournals.org/content/177/11/1279.full.pdf+html

[8]Barua S, Kuizon S, Junaid MA. Folic acid supplementation in pregnancy and implications in health and disease. J Biomed Sci 2014;21(1):77. Disponívelem: doi: 10.1186/s12929-014-0077-z.

[9]Khoushabi F, Shadan, MR, Miri Ali, Sharifi-Rad J. Determination of maternal serum Zinc, Iron, Calcium and Magnesium during pregnancy in pregnant women and umbilical cord blood and their association with outcome of pregnancy. MaterSociomed. 2016 Apr; 28(2): 104-107.

[10] Direção-Geral de Saúde. Programa Nacional para a Vigilância da Gravidez de Baixo risco 2015. In: http://www.saudereprodutiva.dgs.pt/ficheiros-deupload-diversos/pnvgbr-pdf.aspx

[11] Wen SW, et al. Folic Acid Supplementation in Pregnancy and the Risk of Pre-Eclampsia—A Cohort Study. PLoS One 2016. In: http://journals.plos.org/ plosone/article/asset?id=10.1371/journal.pone.0149818.PDF.

[12] Kondo, A. et al. Awareness of folic acid use increases its consumption, and reduces the risk of spina bifida. British Journal of Nutrition 2015; 114:84-90. In: https://www.cambridge.org/core/services/aop-cambridge-core/content/view/F615F2AFC8FEFD0E946C37B64708EC0B/S0007114515001439a. pdf/awareness-of-folic-acid-use-increases-its-consumption-and-reduces-the-risk-of-spina-bifida.pdf.

[13] Alaoddolehei, H.; et al. Efficacy of daily versus intermittent administrationof iron supplementation in anemia or blood indices during pregnancy. Caspian J Intern Med 2014; 4(1):569-573. In:https:/www.ncbi.nlm.nih.gov/pmc/articles/PMC3762232/pdf/cjim-4-569.pdf.

[14] Alwan, N. A.; et al. Maternal iron status in early pregnancy and birth outcomes: insights from the Baby's Vascular health and Iron in Pregnancy study. British Journal of Nutrition 2014; 113(12):1985-1992. In: https://www.cambridge.org/core/journals/british-journal-of-nutrition/article/maternaliron-status-in-early-pregnancy-and-birth-outcomes-insights-from-the-babys-vascular-health-and-iron-in-pregnancy-study/7DE3304FC3AAF38F54C9196859DA2E31.

[15] Lee, H. S.; et al. Iron Status And Its Association With Pregnancy Outcome in Korean pregnant women. European Journal of Clinical Nutrition 2006; 60(9):1130-1135. In: http://www.nature.com/ejen/journal/v60/n9/pdf/1602429a.pdf .

[16] Nwaru BI, et al. An exploratory study of the associations between maternal iron status in pregnancy and childhood wheeze and atopy. Br J Nutr. 2014 Dec;112(12):2018-27. In:

[17] Padmaja, RT; et al. Maternal Myocardial Performance in Second Trimester of Pregnancy With Iron Deficiency Anaemia. Journal of Clinical and Diagnostic Research 2016; 10(3): CC16-CC18. In: https://www.ncbi.nlm.nih.gov/pmc/articles/PMC4843252/pdf/jcdr-10-CC16.pdf.

[18] Walsha, JM; et al. Identification of those most likely to benefit from a low-glycaemic index dietary intervention in pregnancy. British Journal of Nutrition 2014;112:583-589. Disponível em https://www.cambridge.org/core/services/aop-cambridge-core/content/view/3A6A6AAFF54BF81D6C792BE9742C CEE4/S000711451400110Xa.pdf/identification-of-those-most-likely-to-benefit-from-a-low-glycaemic-index-dietary-intervention-in-pregnancy.pdf.

[19] Picciano, MF. Pregnancy and lactation: physiological adjustments, nutritional requirements and the role of dietary supplements. J Nutr, 2003. 133(6): p. 1997s- 2002s. In: http://jn.nutrition.org/content/133/6/1997S.long

[20] Pinto, E., H. Barros, and I. dos Santos Silva, Dietary intake and nutritional adequacy prior to conception and during pregnancy: a follow-up study in the north of Portugal. Public Health Nutr, 2009. 12(7): p. 922-31.

[21] Andresen ST \&Lauberg P. Iodine Supplementation in Pregnancy and the Dilemma of Ambiguous Recommendations. Eur Thyroid J 2012; 5(1):35-43. In: https://www.ncbi.nlm.nih.gov/pmc/articles/PMC4836119/.

[22] Direção-Geral da Saúde. Aporte de iodo em mulheres na preconceção, gravidez e amamentação 2013. In: https://www.dgs.pt/directrizes-da-dgs/orientacoes-e-circulares-informativas/orientacao-n-0112013-de-26082013-png.aspx.

[23] Bakacak, M; et al. Comparison of Vitamin D levels in cases with preeclampsia, eclampsia and healthy pregnant women. International Journal of Clinical and Experimental Medicine 2015; 8(9):16280-16286. In: https://www.ncbi.nlm.nih.gov/pmc/articles/PMC4659033/pdf/ijcem0008-16280.pdf.

[24] Hollis BW, et al. Vitamin D supplementation during pregnancy: Doubleblind, randomized clinical trial of safety and effectiveness. J Bone Miner Res. 2011;26(10):2341-2357.

[25] Ettinger, AS; et al. Effect of calcium supplementation on bone resorption in pregnancy and the early postpartum. Nutrition Journal 2014;13(1). In: http:// nutritionj.biomedcentral.com/articles/10.1186/1475-2891-13-116.

[26] Lee JT, et al. Consumption of Calcium-Fortified Cereal Bars to Improve Dietary Calcium Intake of Healthy Women: Randomized Controlled Feasibility Study. PLoS One 2015;10(5). In: https://www.ncbi.nlm.nih.gov/pmc/articles/PMC4420267/pdf/pone.0125207.pdf .

[27] Juhl, B, Lauszus FF, Lykkesfeldt J. Poor Vitamin C Status Late in Pregnancy Is Associated with Increased Risk of Complications in Type 1 Diabetic Women: A Cross-Sectional Study,Nutrients. 2017 Mar; 9(3): 186.

[28] Martins, I, Porto A, Oliveira L. Tabela de Composição de Alimentos. Departamento de Alimentação e Nutrição. Instituto Nacional de Saúde Doutor Ricardo Jorge. Lisboa, 2010

[29] Conde P, et al. Hipoglicémia na gravidez. ActaObstetGinecolPort 2009; 3(4):205-210. In: http://www.fspog.com/fotos/editor2/1_ficheiro_434.pdf.

[30]Portfir. In: http://portfir.insa.pt/

[31] https://ndb.nal.usda.gov/ndb/search/list

[32] Singh R, De S, Belkheir A. Avena sativa (Oat), A Potential Neutraceutical and Therapeutic Agent: An Overview. Crit Rev Food Sci Nutr. 2013;53(2):12644. In: http://dx.doi.org/10.1080/10408398.2010.526725

[33] Decker EA, Rose DJ, Stewart D. Processing of oats and the impact of processing operations on nutrition and health benefits. Br J Nutr. 2014 Oct;112 Suppl 2:S58-64.

[34] Chitayat D, et al. Folic Acid Supplementation for Pregnant Women and Those Planning Pregnancy: 2015 Update. J ClinPharmacol. 2016 Feb;56(2):1705 .

[35] Wen SW, et al.Effect of Folic Acid Supplementation in Pregnancy on Preeclampsia: The Folic Acid Clinical Trial Study. J Pregnancy. 2013; $2013: 294312$. 
[36] Bunyavanich, S, et al. Peanut, milk, and wheat intake during pregnancy is associated with reduced allergy and asthma in children. J Allergy Clin Immunol. 2014 May; 133(5): 1373-1382. In: http://www.jacionline.org/article/S0091-6749(13)02989-8/fulltext

[37] Greenbaum A, Kayanush JA. Effect of Honey a Natural Sweetener with Several Medicinal Properties on the Attributes of a Frozen Dessert Containing the Probiotic Lactobacillus acidophilus. 2013; 3(2). In:http://file.scirp.org/Html/2-2260033_33291.htm

[38] Sharma A, et al. Artificial sweeteners as a sugar substitute: Are they really safe? Indian J Pharmacol. 2016 May-Jun;48(3):237-40. In: https://www.ncbi. nlm.nih.gov/pme/articles/PMC4899993/

[39] Mohd-Radzman NH, et al. Potential Roles of Stevia rebaudianaBertoni in Abrogating Insulin Resistance and Diabetes: A Review. Evid Based Complement Alternat Med.2013;2013:718049. In: https://www.ncbi.nlm.nih.gov/pmc/articles/PMC3845826/.

[40] Torloni, MR, et al. O uso de adoçantes na gravidez: uma análise dos produtos disponíveis no Brasil. Revista Brasileira de Ginecologia. 2007, 29(5):267275. In: http://dx.doi.org/10.1590/S0100-72032007000500008.

[41] Saenphet K, et al. Safety evaluation of aqueous extracts from Aegle marmelos and Stevia rebaudiana on reproduction of female rats. Southeast Asian J Trop Med Public Health. 2006;37 Suppl 3:203-5. In: https:/www.researchgate.net/publication/6289657_Safety_evaluation_of_aqueous_extracts_from_ Aegle_marmelos_and_Stevia_rebaudiana_on_reproduction_of_female_rats

[42] Wu-Qing H, et al. Excessive fruit consumption during the second trimester is associated with increased likelihood of gestational diabetes mellitus: a prospective study. Sci Rep. 2017; 7: 43620. In: https://www.ncbi.nlm.nih.gov/pmc/articles/PMC5341573/

[43] Bolduc FV, et al. Cognitive Enhancement in Infants Associated with Increased Maternal Fruit Intake During Pregnancy: Results from a Birth Cohort Study with Validation in an Animal Model. EbioMedicine. 2016 Jun;8:331-40. In: https://www.ncbi.nlm.nih.gov/pmc/articles/PMC4919537/

[44] Silveira NGA, Vargas PN, Rosa CS. Teor de Polifenóis e Composição Química do Mirtilo do Grupo Highbush. AlimNutr. 2007; 18(4):365-370. In: http://serv-bib.fcfar.unesp.br/seer/index.php/alimentos/article/viewFile/176/184

[45] Hever J. Plant-Based Diets: A Physician's Guide. Perm J. 2016 Summer; 20(3): 93-101. https://www.ncbi.nlm.nih.gov/pmc/articles/PMC4991921/

[46] Maham, L.K. \& Escott-Stump, S. Krause. Alimentos, nutrição e dietoterapia. 12a Edição. Rio de Janeiro: Elsevier, 2010

[47] Caniço, L. Alimentação e Nutrição em grávidas adultas. Faculdade de Ciências da Nutrição e Alimentação, 2008. In: https://repositorio-aberto.up.pt/bit stream/10216/54442/4/120819 0823TCD23.pdf

[48] Rico R, Bulló M, Salas-Salvadó J. Nutritional composition of raw fresh cashew (Anacardiumoccidentale L.) kernels from different origin. Food Sci Nutr. 2016 Mar; 4(2): 329-338. In: https://www.ncbi.nlm.nih.gov/pmc/articles/PMC4779481/

[49] Hever J, Cronise RJ. Plant-based nutrition for healthcare professionals: implementing diet as a primary modality in the prevention and treatment of chronic disease. J Geriatr Cardiol. 2017 May;14(5):355-368. In: https://www.ncbi.nlm.nih.gov/pubmed/28630615

[50] Arya SS, Salve AR, Chauhan S. Peanuts as functional food: a review. J Food Sci Technol. 2016 Jan;53(1):31-41

[51] Vanhanen LP, Savage GP. Analysis of Pine Nuts (Pinus spp.) Grown in New Zealand Foods. 2013 Apr;2(2):143-150. In: https://www.ncbi.nlm.nih.gov/ pmc/articles/PMC5302263/

[52] Kulczynski K, Gramza-Michalowska A. Goji berry (lyciumbarbarum): composition and health effects - a review. Polish Journal of Food and Nutrition Sciences. 2016; 66(2):67-76. In: http://journal.pan.olsztyn.pl/fd.php?f=1441

[53] Njike VY, et al. Walnut ingestion in adults at risk for diabetes: effects on body composition, diet quality, and cardiac risk measures. BMJ Open Diabetes Res Care. 2015; 3(1): e000115.

[54] Al-Shahib W, Marshall RJ. The fruit of the date palm: its possible use as the best food for the future? International Journal of Food Science and Nutrition. 2003; 2 54:247-259.

[55] Al-Kuran O, et al. The effect of late pregnancy consumption of date fruit on labour and delivery. Journal of Obstetetrics and Gynaecology. 2011;31(1):2931

[56] Razali N, et al. Date fruit consumption at term: Efect on lenght of gestation, labour and delivery. Journal of Obstetetrics and Gynaecology. 2017. In: http://dx.doi.org/10.1080/01443615.2017.1283304

[57] Bianchi CM, et al. Concerns, attitudes, beliefs and information seeking practices with respect to nutrition-related issues: a qualitative study in French pregnant women. BMC Pregnancy Childbirth. 2016 Oct 12;16(1):306. In: https:/www.ncbi.nlm.nih.gov/pmc/articles/PMC5059968/

[58] Sharlin J \& Edelstein Judy. Essencials of Life Cycle Nutrition. Jones and Bartlett Publishers; 2013.

[59] Gewa CA, et al. Fish-enhanced and soybean-enhanced supplemental snacks are acceptable among pregnant women in rural Kenya. Food Nutr Bull. 2014 Dec;35(4 Suppl):S180-7.

[60] Smith A, Stamatakis C. Cereal bars, mood and memory. Current Topics in Nutraceutical Research. 2010 Nov, 8(4):169-172.

[61] Food Standards Agency: Eating while you are pregnan. London: FSA; 2008. In: http://www.food.gov.uk/aboutus/publications/\#branch6.

[62] Tran T, et al.Iron Overdose during Pregnancy: Case and Treatment Review. J EmergMed. 2000 Feb;18(2):225-8.

[63] Valera-Gran D, García de la Hera M, Navarrete-Muñoz EM. Infancia y Medio Ambiente (INMA) Project. Folic acid supplements during pregnancy and child psychomotor development after the first year of life. JAMA Pediatr. 2014;168(11):e142611.

[64] https://www.continente.pt/pt-pt/public/Pages/searchresults.aspx?k=Barra\&tct=Todas\%20as\%20Categorias

[65] https://www.jumbo.pt/Frontoffice/search/barras

[66] https://www.pingodoce.pt/?s=barras\&

[67] https://www.celeiro.pt/produtos/alimentacao/\#!/categorias:barras e snacks

[68] Gouveia, Flávia. Indústria de alimentos: no caminho da inovação e de novos produtos. Inovação Uniemp. 2006; 2(5): 32-37.

[69] https://kerrydotcom-cdn-prod.azureedge.net/-/media/documents/hottopics/cereals-hot-topic.ashx?la=en-gb.

[70] Silva C, et al. Produção e avaliação sensorial de barras de cereais a base de farinha de banana verde. Revista do Agronegócio - Reagro. 2016; 5(76): 76-86. In: http://www.fatecjales.edu.br/reagro/images/artigos/1a edicao/volume5-esp/08-prod-e-avaliacao-sensorial-de-barras-de-cereais-de-farinhade-banana-verde.pdf

[71] Onwulata C, et al. High-fiber snacks extruded from triticale andwheatformulations. Cereal FoodsWorld. 2000; 45, 470-473.

[72] Gutkoski L, et al. Desenvolvimento de barras de cereais à base de aveia com alto teor de fibra alimentar. 2007; 27(2):355-363. In: http://www.scielo.br/ $\mathrm{pdf} / \mathrm{cta} / \mathrm{v} 27 \mathrm{n} 2 / 24 . \mathrm{pdf}$

[73] Direção-Geral da Saúde. Exames laboratoriais na Gravidez de Baixo Risco n³7/2011. In: https://www.dgs.pt/directrizes-da-dgs/normas-e-circularesnormativas/norma-n-0372011-de-30092011-jpg.aspx

[74] Wells, ML, et al. Algae as nutritional and functional food sources: revisiting our understanding. 2017; 29:949-982.

[75] Tang G, Suster PM. Vitamin A, Nutrition, and Health Values of Algae: Spirulina, Chlorella, and Dunaliella. Journal of Pharmacy and Nutrition Sciences. 2011; 1:111-118. In: https://www.researchgate.net/publication/279700076_Vitamin_A_Nutrition_and_Health_Values_of_Algae_Spirulina_Chlorella_and_Dunaliella 